\title{
POPULATION DENSITIES AND BIOMASS OF NEOTROPICAL SOCIAL WASPS (HYMENOPTERA, VESPIDAE) RELATED TO COLONY SIZE, HUNTING RANGE AND WASP SIZE
}

\begin{abstract}
At a locality near Brasilia the sizes of hunting areas and of colonies of 13 species of social wasps varied greatly. Size of the hunting area varied 152 fold and was strongly related to the number of adult wasps per colony which varied 400 fold. The total number of adults of the 13 species was estimated at $182.9 /$ ha (range 7.1 fold among the species) and their total biomass was $1.6 \mathrm{~kg} /$ ha (range 3.6 fold). Hunting range was not significantly related to body size. Variation in wing area ( 11.3 fold) was similar to that of the fresh weight of the adult female ( 10.7 fold $)$. Eleven species showed habitat preferences where they hunted. Models relating prey size to the distance prey are carried are discussed.

KEY WORDS. Vespidae, colony size, densities, hunting area, neotropics
\end{abstract}

Anthony Raw

Social wasps of the family Vespidae are ubiquitous members of lowland neotropical ecosystems. In Central Brazil, as elsewhere in the country, several species occur together (RAW 1988, 1998). Most of the neotropical species of social wasps whose diets are known hunt arthropods and many are foliage gleaners (GoBBI \& MACHADO 1985, 1986; RAVERET-RICHTER \& JEANNE 1985; MACHADO et al. 1987; MACHADO et al. 1988; RAW 1988, in press; RAVERET-RICHTER 1990; MONTILLOR \& BERNAYS 1993). The most obvious differences among the coexisting species are the sizes of the adults and of their colonies and it was suspected that these two characteristics might influence their population densities.

Social wasps lend themselves very well to studies on populations ecology. The relative ease of locating the nests of most species and the strong aggregations when the wasps are at their nests make the task of counting their populations far easier than in solitary animals. Counts of nest populations are more reliable than estimates of the numbers of wasps away from their nests where many individuals can be overlooked.

However, without information on the wasps' hunting ranges, the densities of wasps which might be implied from their colony densities can be misleading. For the present investigation the potential areas tapped by colonies were considered to be circular, though the shape can be expected to vary temporarily with the fluctuating availability of resources. The numbers and sizes of wasp colonies, the body sizes of adult female wasps and their hunting ranges were examined.

1) Departamento de Ciências Biológicas, Universidade Estadual de Santa Cruz. Rodovia Ilhéus - Itabuna Km 16. 70910-900 Ilhéus, Bahia, Brasil.

Revta bras. Zool. 15 (3): 815 - 822, 1998 


\section{Study area}

At a locality in the Cabeça de Veado valley, $12 \mathrm{~km}$ south of the centre of Brasilia ( $\left.15^{\circ} 52^{\prime} \mathrm{S}, 47^{\circ} 52^{\prime} \mathrm{W}\right)$, several species of social wasps hunted together. The total area surveyed was 15 ha $(500 \mathrm{~m} \mathrm{X} 300 \mathrm{~m})$ which comprised the 4 ha $(400 \mathrm{~m}$ $\mathrm{X} 100 \mathrm{~m}$ ) study site and a border 1 ha wide along each side and 0.5 ha beyond each end. The 4 ha study site was a garden bordered on three sides by natural vegetation typical of the region. The western boundary of $400 \mathrm{~m}$ was the edge of evergreen, riparian forest along a permanent stream while to the south and east there was "campo limpo" and "campo sujo". These are forms of open cerrado; the savanna-like vegetation typical of Central Brazil described by EITEN (1972). A house was situated in the south-west corner of the study area and to the north were neighbouring gardens.

The garden where the study was conducted contained numerous native and exotic tropical trees and shrubs. There were also annual fruit, vegetable and many ornamental plants interspersed with lawns. The native trees included Byrsonima umbellata A.Juss. (Malpighiaceae), Cassia ferruginea (Schrad.) Schrad. ex DC. (Leguminoseae), Jacaranda cuspidifolia Mart. and Tabebuia impetiginosa (Mart.) Standl. (Bignoniaceae) and Tapirira guianensis Aubl. (Anacardiaceae).

\section{METHODS}

In order to estimate the total numbers of social wasps in the study area, their colonies were located and the number of occupants in the smaller nests were counted and, in the larger nests, were estimated. Species of Polistes Latreille, 1802 and Mischocyttarus de Saussure, 1863 construct open nests with a single exposed comb on which all the wasps are visible. The numbers of adult female wasps on each of the nests of this type were counted between $06.00 \mathrm{hr}$ and $06.40 \mathrm{hr}$ before the wasps became active. Males are common in medium-sized and large colonies of Mischocyttarus, but are easily distinguished from the females. The nests of the other species studied are totally enclosed in a paper outer wall so nests were collected in order to count the number of adult occupants. The large colony of Polybia ignobilis (Haliday, 1836) was inaccessible so the colony size was estimated based on counts of three colonies of similar size located 8,19 and $23 \mathrm{~km}$ from the study area.

In February, 1987 the total area of 15 ha was searched during 16 hours for wasps and their nests. During the following six weeks the 4 ha study site was searched two hours per day, three days per week for hunting wasps. On each occasion that a wasp was seen its exact location in the garden was noted and the distance from the wasp to the nearest nest of that species was measured to within $1 \mathrm{~m}$ for ten of the species and within $5 \mathrm{~m}$ for Synoeca surinama (Linnaeus, 1767) and $10 \mathrm{~m}$ for $P$. ignobilis and Epipona tatua (Cuvier, 1797).

The hunting ranges were measured in order to compare the areas used by the colonies. The mean of the 25 longest distances from the nest (of the 30 to 42 recorded) for each species was used as the radius of the circle (here called the hunting range) of the area utilized for hunting and foraging. Each time a wasp was located the vegetation type of the place was also recorded. The vegetation was categorized

Revta bras. Zool. 15 (3): 815 - 822, 1998 
simply as either open areas without trees (lawn, flower beds and vegetable plots) or under trees which were $4 \mathrm{~m}$ to $6 \mathrm{~m}$ tall. At the boundary between the two vegetation types the wasps which were encountered in sunny locations were considered to be in open areas and those in shade under trees.

Twenty adult females of each species were starved for three or four hours and then weighed to $10^{-4} \mathrm{~g}$ and the lengths of their fore-wings measured to $10^{-4} \mathrm{~m}$. Only eight females of Mischocyttarus goyanus Zikán, 1949 were measured. The biomass of adults per hectare for each species was calculated using the data on fresh starved body weight and the estimated densities of wasps in the study area.

\section{RESULTS}

\section{Numbers of colonies}

Thirteen species of social wasps hunted in the study area of 4 ha (Tab. I). Twenty nine active colonies of ten species were discovered in the area. Those of Mischocyttarus cerberus Ducke, 1918, M. cassununga (von Ihering, 1903), M. goyanus, Polistes satan Bequaert, 1940 and Parachartergus fraternus (Gribodo, 1892) were attached to the roof and window frames of the house. Nests of Pseudopolybia vespiceps (de Saussure, 1864), Polybia fastidiosuscula de Saussure, 1854, P. occidentalis (Olivier, 1791), P. paulista von Ihering, 1896 and Brachygastra augusti (de Saussure, 1854) were suspended from the branches of trees. The colonies of Polybia paulista, P. occidentalis, Parachartergus fraternus and Brachygastra augusti were located near the corners of the study area. The three other species that hunted in the study area had established colonies outside the garden. The nest of E. tatua was suspended from a branch at the forest edge $90 \mathrm{~m}$ from the edge of the study area. The nest of $S$. surinama was $50 \mathrm{~m}$ and that of $P$. ignobilis was $150 \mathrm{~m}$ distant in the forest. The first was affixed to a tree trunk and the second was located inside a hollow tree.

In the survey of the entire 25 ha plot a total of 23 species was located. These included one colony each of Synoeca surinama, E. tatua and P. ignobilis whose members hunted in the study site. Of the 10 species which nested in the 4 ha plot colonies of only $M$. cerberus, Polistes satan and Polybia occidentalis were found in the surrounding area with respectively eight, two and one colonies.

\section{Densities of wasp populations}

In some instances, the nests of different species were located close together. The closest nests of four of the five species that nested on the house (three species of Mischocyttarus and Polistes satan) were only $20 \mathrm{~cm}$ to $5 \mathrm{~m}$ apart. The nests of Polybia occidentalis and B. augusti were $2 \mathrm{~m}$ apart in a Cassia tree $100 \mathrm{~m}$ from the house, a large nest of P. paulista was located in a Schizolobium parahyba (Vell.) Blake tree $25 \mathrm{~m}$ distant and a nest of Ps. vespiceps in an unidentified tree $40 \mathrm{~m}$ distant. The nest of $P$. fastidiosuscula was suspended from the branch of an unidentified tree $25 \mathrm{~m}$ from the house. Dividing the study area into four 1-ha plots, 25 colonies were located within one of the plots which contained the house and 4 were in a second plot, whereas colonies were not found in two plots. 
The numbers of adult wasps of the 13 species in the 4 ha study area ranged from 12.7 to 90.7 (Tab. I), so the density of the most abundant species was 7.1 times greater than the rarest one. The hunting areas of ten of the species extended beyond the limits of the study area and the number of active wasps of these was calculated to be 575.6 , while the number of wasps of the three species with smaller colonies whose hunting areas were entirely contained within the study area totalled 156 (Tab. I). Thus the number of adult female wasps that occupied the study area of 4 ha was estimated to be 731.6 which gives a mean of 182.9 adult wasps / ha. The number of adult female wasps per colony varied from 5 to 2,000 among the species; a 400 fold difference (Tab. II). Colony size was strongly correlated with the size of the hunting area $\left(\mathrm{r}^{2}=0.948, \mathrm{P}<0.00001\right.$; figure 1).

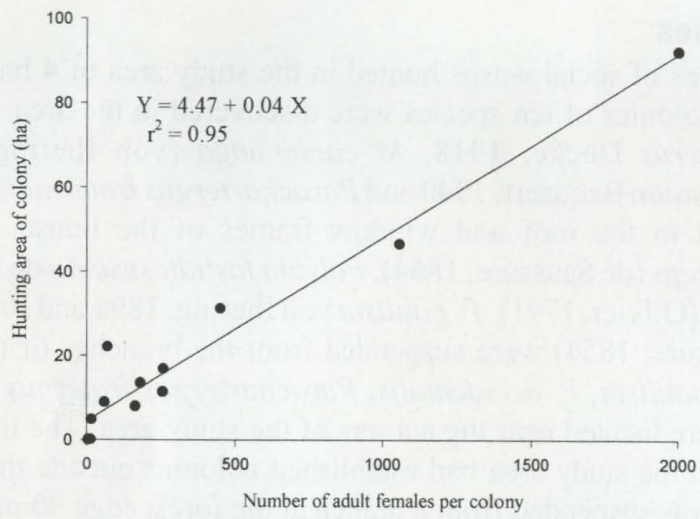

Fig. 1. The relationships of colony size to hunting area in 13 species of social wasps at a locality near Brasilia.

Table I. The sizes of colonies and hunting areas, densities and biomass of 13 species of social wasps in an area of four hectares near Brasilia. The colonies of three species (marked *) were outside the study area.

\begin{tabular}{lcccccc}
\hline Species & $\begin{array}{c}\text { Number of } \\
\text { colonies in study } \\
\text { area }\end{array}$ & $\begin{array}{c}\text { Mean number of Hunting area per } \\
\text { adults females } \\
\text { per colony }\end{array}$ & $\begin{array}{c}\text { Number of adult } \\
\text { females in study } \\
\text { area (4ha) }\end{array}$ & $\begin{array}{c}\text { Mean fresh } \\
\text { starved weight } \\
\text { per wasp (mg) }\end{array}$ & $\begin{array}{c}\text { Biomass (fresh } \\
\text { weight in mg) of } \\
\text { wasps in study } \\
\text { area (4ha) }\end{array}$ \\
\hline M. cerberus & 10 & 5 & 0.06 & 50.0 & 23.5 & 1175.0 \\
M. goyanus & 4 & 7 & 0.07 & 28.0 & 47.5 & 1330.0 \\
M. cassununga & 6 & 13 & 0.10 & 78.0 & 28.7 & 2238.6 \\
P. satan & 3 & 16 & 4.91 & 13.0 & 157.2 & 2048.7 \\
P. vespiceps & 1 & 60 & 8.98 & 26.7 & 46.0 & 1229.9 \\
S. surinama & $*$ & 70 & 22.10 & 12.7 & 147.2 & 1867.5 \\
P. fastidiosuscula & 1 & 164 & 8.00 & 82.6 & 14.7 & 1213.7 \\
B. augusti & 1 & 181 & 13.50 & 53.8 & 32.1 & 1725.8 \\
P. fraternus & 1 & 257 & 11.40 & 90.6 & 36.4 & 3298.1 \\
P. occidentalis & 1 & 259 & 16.90 & 61.2 & 16.2 & 992.1 \\
E. tatua & $*$ & 450 & 31.20 & 57.7 & 53.3 & 3076.5 \\
P. paulista & 1 & 1056 & 46.60 & 90.7 & 21.3 & 1931.3 \\
P. ignobilis & $*$ & 2000 & 92.30 & 86.6 & 41.6 & 3604.6 \\
\hline
\end{tabular}


Table II. Summary of ranges of values of various measurements of 13 species of social wasps hunted at a locality near Brasilia.

\begin{tabular}{|c|c|c|c|}
\hline & & Range & Difference factor \\
\hline Biomass (weight of adults- $\mathrm{g} / \mathrm{ha}$ ) & 0.29 & -0.90 & 3.1 \\
\hline Population density & 20.20 & - 90.7 & 7.1 \\
\hline Length of forewing $(\mathrm{mm})$ & 6.40 & $-\quad 21.5$ & 3.4 \\
\hline Body weight $(\mathrm{mg})$ & 14.70 & -157.2 & 10.7 \\
\hline Hunting area (ha) & 0.06 & - $\quad 92.3$ & 154.0 \\
\hline Colony size (number of adults) & 5.00 & -2000.0 & 400.0 \\
\hline
\end{tabular}

\section{Sizes of adult wasps and biomass}

The mean lengths of the fore-wings varied 3.4 fold $(6.4 \mathrm{~mm}$ to $21.5 \mathrm{~mm})$ from the shortest to the longest species studied, while the range of the fresh starved body weight varied by a factor of 10.7 (Tab. II). The total biomass (fresh starved weight of adult female wasps) of the 13 species in the 4 ha study was $25.7 \mathrm{~g}$; equivalent to $6.4 \mathrm{~g} / \mathrm{ha}$ (Tab. I). The biomass varied by a factor of 3.1 among the species. The lowest was $P$. occidentalis, followed by $P$. fastidiosuscula, and the highest was $P$. ignobilis.

\section{Hunting ranges}

A total of 443 distances was measured from where wasps were encountered to their nests. The total number of measurements per species ranged from 30 to 42 . The mean hunting ranges varied twelve fold, from $44 \mathrm{~m}$ to $542 \mathrm{~m}$ among the species. The correlation of the hunting range with length of the fore-wing of the 13 species was not significant $\left(\mathrm{r}^{2}=-0.102, \mathrm{P}=0.740\right)$.

Hunting areas were calculated from the above distances. They varied from 0.6 ha to 92.3 ha (a 152 fold range) (Tab. I). The sizes of the hunting areas could be conveniently placed in two categories and one species was intermediate. The total areas used for hunting by the three species with the shortest hunting ranges (the three Mischocyttarus species) were contained entirely within the garden and covered $15 \%, 18 \%$ and $24 \%$ of the study area. The nests of the three Mischocyttarus species and $P$. satan were built very close together and consequently the colonies' hunting areas overlapped. The 4 ha area comprised only part (4\% to $50 \%)$ of the estimated hunting area of the nine remaining species and, in particular it comprised only small parts ( $4 \%, 13 \%$ and $18 \%$ ) of the hunting areas of the three species with the longest hunting ranges and whose nests were located further afield. $P$. satan is intermediate and the garden comprised $81 \%$ of its hunting area. These hunting areas were used to calculate the densities of the populations of the 13 species (Tab. I).

\section{Habitat use}

The vegetation cover of the study area is heterogeneous, encompassing areas of trees and open vegetation and included patches where some species hunted and others where they did not. The 13 species hunted over many types of plants and their hunting areas overlapped partially or totally. However, 11 of the species showed significant preferences between open and shaded vegetation (Tab. III, Chi-square test). Most individuals of the three Mischocyttarus species, S. surinama, 
Polybia fastidiosuscula and Parachartergus fraternus were found in shade under trees. In contrast Polistes satan, Polybia occidentalis, P. paulista, B. augusti and E. tatua were seen more often in more open places on the arable crops and flower beds. Approximately $70 \%$ of the study area was in full sun at mid-day. Only P. ignobilis and Polistes satan were seen hunting on the lawn.

Table III. The utilization of open and shaded vegetation by 13 species of social wasps hunted at a locality near Brasilia.

\begin{tabular}{lcccc}
\hline \multicolumn{1}{c}{ Species } & $\begin{array}{c}\text { Nember of } \\
\text { observations }\end{array}$ & $\begin{array}{c}\text { Nember (and percentage) } \\
\text { in open locations }\end{array}$ & $\begin{array}{c}\text { Value of P } \\
\text { (Chi-square) }\end{array}$ \\
\hline Mischocyttarus cerberus & 66 & 4 & $(6)$ & $<0.001$ \\
Synoeca surinama & 45 & 7 & $(16)$ & $<0.01$ \\
Mischocyttarus cassununga & 54 & 5 & $(9)$ & $<0.001$ \\
Polybia fastidiosuscula & 72 & 8 & $(11)$ & $<0.001$ \\
Parachartergus fraternus & 60 & $13(22)$ & $<0.01$ \\
Mischocyttarus goyanus & 41 & $11(27)$ & $<0.05$ \\
Pseudopolybia vespiceps & 37 & $13(35)$ & NS \\
Polybia ignobilis & 89 & $54(61)$ & $<0.01$ \\
Polybia paulista & 94 & $66(70)$ & $<0.01$ \\
Polistes satan & 68 & $62(91)$ & $<0.001$ \\
Polybia occidentalis & 61 & $57 \quad(93)$ & $<0.001$ \\
Brachygastra augusti & 54 & $54(100)$ & $<0.001$ \\
Epipona tatua & 35 & $35(100)$ & \\
\hline
\end{tabular}

(NS) Not significant at the $5 \%$ level.

\section{DISCUSSION}

The wasps were counted or their numbers estimated at their nests in the present investigation so the data on population sizes are considered to be more accurate than counts of wasps when they are hunting and foraging. Often it is difficult to locate individual wasps in dense vegetation and in tree tops and many are overlooked. The estimates of hunting range of nine of the species are also considered to be relatively accurate. However, the mean hunting ranges of four were $>240 \mathrm{~m}$ and they might have been under estimated in a study area $400 \mathrm{~m}$ long. The wasps are the three whose colonies were located outside the study area and Polybia paulista whose nest was located near one end of the study area. Nonetheless, no additional colonies of these four species were encountered in the 25 ha plot; the only ones being those cited in table I.

As seen in the present investigation, very often relatively large colonies are encountered close together due to the limited availability of nest sites. More than half the study area contained no colony - possibly through a lack of suitable nest sites. Likewise, DINIZ \& KITAYAMA (1994) recorded eight colonies of six species of Polybia in a single hectare of gallery forest in Mato Grosso state also in Central Brazil.

During the present study, quantitative information was not collected on the levels of predation. However, a larger colony is said to furnish the advantage of a high of survivorship of its occupants. In particular, larger colonies may suffer fewer attacks and be able to re-establish themselves more quickly than smaller ones (JEANNE 1975, 1980). 
The hunting areas of the 13 species overlapped partially or totally. However, a factor believed to be important in niche separation is the significant preferences which the species demonstrated between the two types of habitat where they hunted. Eleven of them could be classified as either forest or open area species according to the type of habitat in which they hunted in natural vegetation and in equivalent vegetation types in the garden. The neotropical social wasps which have been investigated restrict their hunting to broad habitat types (RAw 1992, 1998). Several species nest in the forest and hunt in adjacent open areas (RAW 1988).

The biomass and population densities of the adult females of all 13 species in the study area were relatively low (varying by factors of 3 and 7) and the two factors expressing body size were similar. In marked contrast, the ranges of measurements of hunting range and colony size were very large (154 and 400 fold). The strong correlation between hunting range and colony size demonstrates that the members of a larger colony hunt over a wider area in their search for the resources which the colony requires.

The rich social wasp fauna of the Cabeça de Veado valley may be explained partly by the location of the study area being at the margin of the forest. The forest edge is a rich habitat in tropical Brazil with a greater diversity and abundance of social wasps than either forest or open savanna (RAW 1992, 1998) which may account for the high density of wasps in the study area compared with nearby areas of open savanna (HENRIQUES et al. 1992).

ACKNOWLEDGEMENTS. I thank Mr. John N. Landers on whose property the study was conducted. Dr. James Carpenter of the American Museum of Natural History, New York kindly criticized an early version of the manuscript. I am especially grateful to Dr. John D. Hay, Departamento de Ecologia, Universidade de Brasília and to two unknown reviewers for their invaluable comments on the manuscript.

\section{REFERENCES}

DiniZ, I.R. \& K. Kitayama. 1994. Colony densities and preferences for nest habitats of some social wasps in Mato Grosso state, Brazil (Hymenoptera, Vespidae). Jour. Hymen. Res. 3: 133-143.

EITEN, G. 1972. The cerrado vegetation of Brazil. Botan. Rev. 38: 201-341.

GoBBI, N. \& V.L.L. MACHADO. 1985. Material capturado e utilizado na alimentação de Polybia (Myrapetra) paulista Ihering, 1896 (Hymenoptera - Vespidae).

An. Soc. Entomol. Brasil 14: 189-195.

1986. Material capturado e utilizado na alimentação de Polybia (Trichothorax) ignobilis (Haliday, 1836) (Hymenoptera, Vespidae). An. Soc. Entomol. Brasil 15: 117-125.

HENRIQUES, R.P.B.; I.R.D. RochA \& K. KiTAYAMA. 1992. Nest density of some wasp species in cerrado vegetation of central Brazil (Hymenoptera: Vespidae).

Entomol. Gener. 17: 265-268.

JEANNE, R.L. 1975. The adaptiveness of social wasp nest architecture. Q. Rev. Biol. 50: $267-287$. 
1980. Evolution of social behavior in the Vespidae. Ann. Rev. Entomol. 25: $371-396$.

Machado, V.L.L.; N. GobBi \& V.V. AlVES JR. 1988. Material capturado e utilizado na alimentação de Polybia (Trichothorax) sericea (Olivier, 1791) (Hymenoptera, Vespidae). Revta bras. Ent. 5: 261-266.

Machado, V.L.L.; N. GobBi \& D. SimÕES. 1987. Material capturado e utilizado na alimentação de Stelopolybia pallipes (Olivier, 1791) (Hymenoptera - Vespidae). An. Soc. Entomol. Brasil 16: 73-79.

MONTILlOR, C.B. \& E.A. BERNAYS. 1993. Invertebrate predators and caterpillar foraging, p.170-202. In: N.E. STAMP \& T.M. CASEY (Eds). Caterpillars; Ecological and Evolutionary Constraints on Foraging. New York, Chapman \& Hall, 587p.

RAVERET-RICHTER, M. 1990. Hunting social wasp interactions: influence of prey size, arrival order, and wasp species. Ecology 71: 1018-1030.

RAVERET-Richter, M.A. \& R.L. JEANNE. 1985. Predatory behavior of Polybia sericea (Olivier), a tropical social wasp (Hymenoptera: Vespidae). Behav. Ecol. Sociobiol. 16: 165-170.

RAW, A. 1988. Social wasps (Hymenoptera, Vespidae) and insect pests of crops of the Suruí and Cinta Larga indians in Rondônia, Brazil. Entomologist 107: 104-109.

1992. The forest: savanna margin and habitat selection by Brazilian social wasps (Hymenoptera: Vespidae), p.499-511. In: P.A. FURLEY, J.A. RATTER \& J. PROCTOR (Eds). The Nature and Dynamics of the Forest-Savanna Boundary. London, Chapman \& Hall, 616p.

1998. Social wasps (Hymenoptera, Vespidae) of the Ilha de Maracá, p.311-325. In: J.A. RATTER \& W. MILLIKEN (Eds). Maracá. The Biodiversity and Environment of an Amazonian Rainforest. Chichester, John Wiley \& Sons, 508p.

- (in press). The third trophic level of plant defence: Neotropical social wasps' use of odours of freshly damaged leaves when hunting. Revta bras. Zool..

Recebido em 15.V.1997; aceito em 28.VIII.1998. 


\section{NORMAS PARA PUBLICAÇÃO}

A REVISTA BRASILEIRA DE ZOOLogIA (RBZ), Órgão da SocIEDADE BRASILEIRA DE ZOOLOGIA (SBZ), destina-se a publicar trabalhos científicos originais de Zoologia, de sócios quites com a Tesouraria. A RBZ publica(rá) ainda RESENHAS BibliográficAs, NotAs Gerais e NECROLÓgICOS.

\section{MANUSCRITOS}

Os trabalhos devem ser redigidos em português, inglês ou espanhol; o aceite de outros idiomas ficará a critério da "Comissão Editorial". Os trabalhos devem ser enviados no original e duas cópias (inclusive das figuras). Devem ser digitados em espaço duplo e com margens largas. Alterações de pequena monta serão feitas pela "Comissão Editorial". Correções e acréscimos encaminhados pelo(s) autor(es) após o registro do manuscrito poderão ser recusados. Manuscritos em disquete, redatados em qualquer editor de texto (mencionar o nome do programa utilizado), devem acompanhar os três manuscritos impressos. A página de rosto deve conter: (1) título do trabalho, sucinto, porém, quando apropriado, mencionar o(s) nome(s) $\mathrm{da}(\mathrm{s})$ categoria(s) superior(es) à qual o(s) animal(ais) pertence(m); (2) nome(s) do(s) autor(es) com os respectivos algarismos arábicos para remissão ao rodapé; (3) resumo em inglês, incluindo o título do trabalho se o mesmo for em outro idioma; (4) palavras chaves em inglês; (5) rodapé com endereço profissional (preferencialmente) do(s) autor(es), incluindo: (5.1) departamento ou unidade equivalente; (5.2) instituição; (5.3) caixa postal ou logradouro; (5.4) código de endereçamento postal; (5.5) cidade; (5.6) estado ou equivalente; (5.7) país. No texto serão escritos em itálico, os nomes do grupo gênero, do grupo espécie e palavras estrangeiras. Não devem ser usados quaisquer outros sinais de marcação ou ênfase. A primeira citação de um taxa no texto, deve vir acompanhada do nome científico por extenso, com autor e data (de vegetais se possível), e a família.

As citações bibliográficas serão em CAIXA ALTA (maiúsculas) e dos seguintes modos: SMITH (1990); (SMITH 1990); SMITH (1990: 128); LENT \& JURBERG (1965); GUIMARÃES et al. (1983); artigos do(s) mesmo(s) autor(es) devem ser citados em ordem cronológica.

\section{ILUSTRAÇÕES E TABELAS}

Fotografias, desenhos, gráficos e mapas serão denominados figuras. Devem ser numeradas com algarismos arábicos e chamadas no texto em ordem crescente.

As figuras (desenhos, mapas e gráficos) devem ser feitos a traço de nanquim. As fotografias devem ser nítidas e contrastadas. Não misturar fotografias e desenhos em uma mesma figura.

Em qualquer situação, as figuras devem acompanhar o trabalho em separado, com a indicação no texto de sua localização, marcadas no verso com o(s) nome(s) do(s) autor(es) e título do trabalho; montadas em cartolina branca (quando possível, não maiores que a folha de papel ofício), proporcionais às dimensões do espelho $(11,5 \times 18 \mathrm{~cm})$ e reservando um espaço para a legenda.

A relação de tamanho da figura, quando necessária, deve ser apresentada em escala vertical ou horizontal.

Figuras coloridas podem ser aceitas desde que a diferença dos encargos seja paga pelo(s) autor(es). 
As tabelas devem ser numeradas com algarismos romanos e compiladas em folhas separadas.

As legendas devem ser datilografadas em folha à parte, sendo para cada figura, tabela ou conjunto de figuras ou tabelas, um parágrafo distinto.

\section{AgRAdecimentos}

Agradecimentos e indicações de financiamentos devem ser relacionados antes do item REFERÊNCIAS BIBLIOGRÁFICAS.

\section{REFERÊNCIAS BIBLIOGRÁFICAS}

As REFERÊNCIAS BIBLIOGRÁFICAS, mencionadas no texto, devem ser arroladas no final do trabalho, como nos seguintes exemplos:

1) Periódicos (abreviaturas de acordo com o World List of Scientific Periodicals ou como indicado pelo próprio periódico):

SMITH, D.R. 1990. A synopsis of the sawflies (Hymenoptera, Symphita) of America South of the United States: Pergidae. Revta bras. Ent. 34 (1): 7-200.

LENT, H. \& J. JURBERG. 1980. Comentários sobre a genitália externa masculina em Triatoma Laporte, 1832 (Hemiptera, Reduviidae). Rev. Brasil. Biol. 40 (3): 611-627.

GUIMARÃES, J.H.; N. PAPAVERO \& A.P. DO PRADO. 1983. As miíases da Região Neotropical (identificação, biologia, bibliografia). Revta bras. Zool. 1 (4): $239-416$.

2) Livros, folhetos, etc.:

HENNIG, W. 1981. Insect phylogeny. Chichester, John Wiley, XX+514p.

3) Capítulo de livro:

HULL, D.L. 1974. Darwinism and historiography, p. 388-402. In: T.F. GLICK (Ed.). The comparative reception of Darwinism. Austin, Univ. Texas, IV+505p.

Não serão aceitas referências de trabalhos não publicados.

\section{SePARATAS}

Todos os trabalhos serão reproduzidos em separatas, em número fixo de 50 , e fornecidas gratuitamente ao(s) autor(es).

\section{EXEMPLARES TESTEMUNHA}

Quando apropriado, os manuscritos devem mencionar a coleção da instituição onde podem ser encontrados os exemplares que documentam a identificação taxonômica.

\section{RESPONSABILIDADE}

O teor científico é de inteira responsabilidade do(s) autor(es). 